\title{
Diagenetic changes in Concholepas concholepas shells (Gastropoda, Muricidae) in the hyper-arid conditions of Northern Chile - implications for palaeoenvironmental reconstructions
}

\author{
N. Guzmán ${ }^{1}$, Y. Dauphin ${ }^{2}$, J. P. Cuif ${ }^{2}$, A. Denis ${ }^{2}$, and L. Ortlieb ${ }^{1}$ \\ ${ }^{1}$ UR 055 Paleotropique, IRD, 32 av. H. Varagnat, 93143 Bondy cedex, France \\ ${ }^{2}$ UMR IDES 8148, bât. 504, Université Paris XI-Orsay, 91405 Orsay cedex, France
}

Received: 30 October 2007 - Published in Biogeosciences Discuss.: 6 February 2008

Revised: 22 December 2008 - Accepted: 28 December 2008 - Published: 16 February 2009

\begin{abstract}
Variations in the chemical composition of fossil biogenic carbonates, and in particular of mollusc shells, have been used in a range of palaeoenvironmental reconstructions. It is of primary importance, therefore, to detect and understand the diagenetic processes that may modify the original chemical signature. This microstructural and biogeochemical study focuses on modern and fossil (Holocene and Pleistocene) shells of a littoral gastropod of Northern Chile, and on the characterization of mineral component transformations at the nanometric scale and concomitant intracrystalline organic compound modifications. The inner aragonite layer of the shell exhibits more complex deteriorations than the calcite layer. This preliminary study confirms that physical and chemical alterations of various components of mollusc shell biocrystals are complex and might manifest in different ways even within a single individual. The single criterion of determining the mineralogical composition to verify the conservation state of shell samples is insufficient.
\end{abstract}

\section{Introduction}

Since Urey et al. (1951) calculated palaeotemperatures derived from a belemnite using its oxygen isotopic composition, numerous attempts have been made to use fossil samples as proxies for palaeoclimate and palaeoecological reconstructions. In their pioneering key paper, Urey et al. (1951) pointed out three major problems with this approach: 1) the

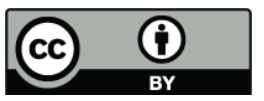

Correspondence to: N. Guzmán (Nury.Guzman@ird.fr) precision of mass spectrometers, 2) "vital effects" which refer to the physiology and metabolism of the sampled organisms, and 3) diagenetic alteration. Whereas major technical improvements were obtained in the sensitivity of mass spectrometers during the last half-century, the uncertainties about vital effects and diagenetic changes have not been significantly reduced. Fifty years later, the so-called vital effects remain mysterious, but are often invoked to account for all the differences observed in the geochemical composition of carbonates between true biogenic samples and what theoretical models predict. The concept is frequently used as a "black box" that conceals our ignorance of the in-depth and complex processes controlling the elemental and isotopic composition of the biocarbonates. Regarding the issue of diagenetic alteration to which Urey referred (Urey et al., 1951), little progress has been made. Apart from assessing the degree and extent of mineralogical re-crystallisation, generally determined through X-ray diffraction, limited efforts have been dedicated to the understanding of the early diagenetic modification of geochemical signals in carbonate skeletons.

The accuracy of information extracted from the chemical composition of shells depends on understanding the behaviour of their components during taphonomic and diagenetic processes. Despite their apparent commonplace mineralogy (i.e., calcite and aragonite), biocrystals have morphological, chemical, and physical properties that are never observed in corresponding abiotic crystals. Biominerals are biocomposites with organic macromolecules within the crystalline units. Knowledge of the structure and composition of these macromolecules is still limited, as is their role in the fossilization process. Nevertheless, in most palaeoenvironmental studies based upon geochemical

Published by Copernicus Publications on behalf of the European Geosciences Union. 
proxies in biocarbonates, the primary, if not the only, criterion commonly used to assess the lack of diagenetic processes is the homogeneity of the mineralogical composition of the sample. A few percent of calcite detected in an aragonite skeleton is considered as an indication of diagenetic alteration. If "diagenesis" is meant to refer to any modification of the original composition of the biomineral, then it should be clear that many processes may occur as well as the extreme case of mineralogical transformation of part (or all) of the original carbonate. Furthermore, this kind of criterion may not apply in all cases in which the original biocarbonate is essentially made of calcite, or Mg-calcite. DeNiro and Weiner (1988) have shown that the diagenetic changes in the organic matrices of fossil bones induce biases in isotopic composition. Similar studies in carbonate skeletons are scarce.

In a study of bivalve shells from Peru and Northern Chile, Perrier et al. (1994) have shown that stable isotope variations can be related to thermal anomalies linked to regional ENSO impacts. This study opened up the possibility of reconstructing ENSO events at different time scales using shells from different time periods. However, most of the species within shell midden or fossil deposits in Peru and Northern Chile area are gastropods. The gastropod Concholepas is one of the most abundant species in archaeological sites. Falabella et al. (1991), Ortlieb et al. (1996, 1997) and Kennett (2003) have already used stable isotopes in Concholepas in attempts to reconstruct sea water temperatures during different periods, but little attention has been paid to the diagenetic stage of the studied material. In contrast, Labonne and HillaireMarcel (2000) in a detailed study, suggested that diagenetic alteration may be rapid enough to preclude palaeoenvironmental reconstructions based on geochemical analyses.

In this study, we compare the microstructures, nanostructures and chemical composition of modern and fossil Concholepas shells in order to investigate any evidence of changes induced by diagenetic processes. This work focuses on understanding some aspects of diagenetic effects particularly those that may control alteration of the original geochemical composition. Variations in the geochemical composition (oxygen and carbon stable isotopes) of the modern and fossil shells obtained from previous preliminary studies are also considered.

\section{Materials and methods}

\subsection{Material}

Concholepas concholepas (Bruguière, 1789) (Gastropoda, Muricidae), also called the Southern Hemisphere abalone, is a carnivorous coastal mollusc abundant along the coasts of Chile and southern Peru. Its edible large foot muscle has been a major food source since prehistoric times, which explains the large numbers of shells of this species in archaeo- logical sites, covering the whole Holocene period. Its habitat ranges from the intertidal zone to $40 \mathrm{~m}$ depth (DuBois et al., 1980). For this study, live samples of adult $C$. concholepas were collected in the Antofagasta area (Santa Maria Island, $23^{\circ} \mathrm{S}$ ), Northern Chile, at depths of about $5 \mathrm{~m}$. A midHolocene sample (AJL) is from an archaeological site located at Juan Lopez Caleta Abtao (L. O. field sample \# C00-417), at the southern end of Mejillones Peninsula, to the northwest of the town of Antofagasta. The site of the Caleta Abtao consists of an accumulation of kitchen refuse that yielded radiocarbon ages between 5350 and 3500 years BP (Llagostera, 1992). Shells collected at another midHolocene archaeological site located at Guanillos $\left(21^{\circ} \mathrm{S}\right)$, about $200 \mathrm{~km}$ north of Caleta Abtao, were also analyzed.

The Pleistocene fossil shell (FM) was collected at Michilla, $100 \mathrm{~km}$ north of Antofagasta (L. O. field sample \# C93-58), in a thin, sandy coastal deposit formed during the last interglacial maximum (isotopic stage 5, 120 ka) (Ortlieb et al., 1996). The hyper-arid conditions of the northern coast of Chile (Atacama Desert), considered as one of the driest places on earth, are favourable for the preservation of fossil shells.

\subsection{Methods}

\subsubsection{Scanning Electron Microscopy (SEM)}

Polished sections and some broken pieces of shells were etched with formic and hydrochloric acid to reveal microstructural features. SEM observations were conducted with Philips SEM 505 and XL30 microscopes (Géologie, Université Paris XI). Procedures for sample preparations are given in the figure legends.

\subsubsection{Atomic Force Microscope (AFM)}

AFM observations were conducted using a Digital Instruments (Veeco) Nanoscope III Dimension 3100 (Géologie, Université Paris XI), at room temperature. The probe consisted of a cantilever with integrated $\mathrm{Si}_{3} \mathrm{~N}_{4}$ tips (Digital Instruments). Micron-scale images were acquired using the tapping mode. The AFM maps the surface topography and simultaneously provides two views of a given sector: a height and a phase images. Height images show surface corrugations (comparable to SEM secondary images), whereas phase images reflect differences in material properties, including viscosity and adhesiveness. Sample surfaces were polished, then slightly etched (details of the etching processes are given in the explanations of the figures). No coating was necessary.

\subsubsection{Energy Dispersive Spectroscopy (EDS)}

Energy-dispersive X-ray microanalysis on shell sections was undertaken using a Cambridge Stereoscan 200 SEM equipped with a solid-state X-ray detector (IRD, Bondy). 
Quantitative analyses of elements were performed using the Link AN10000 analysis system with the ZAF/PB program that estimates peak-to-background element ratios. Samples were embedded in resin and polished with diamond paste. The surface was then lightly etched in 5\% formic acid for $15 \mathrm{~s}$ to reveal structural details within the samples (e.g., different layers) so that the analysis positions could be related to structural features. Measurements were made using a dwelltime of 100 seconds. Analyses were obtained with an accelerating voltage of $15 \mathrm{kV}$ and a spot size of 100 or $200 \mathrm{~nm}$. A cobalt standard provided the instrument calibration.

The elements $\mathrm{Ca}, \mathrm{Na}, \mathrm{Mg}, \mathrm{Sr}, \mathrm{Al}, \mathrm{S}, \mathrm{P}, \mathrm{K}, \mathrm{Fe}$ and $\mathrm{Mn}$ were selected to illustrate aspects of shell composition and diagenetic changes. Some elements are below or near the detection limit for the microprobe, particularly in Holocene shells, but this information is important because it allows for a direct comparison with fossil samples. A minimum of 10 analyses were made at various locations on each layer of each shell section. These analyses were then averaged to obtain an individual sample mean.

\subsubsection{Fourier Transform Infrared Spectrometry (FTIR)}

The two layers (calcite and aragonite) of the cleaned shells were separated. Small pieces of shell were immersed in 3\% $\mathrm{NaClO}$ solution to remove organic contaminants, and then rinsed with Milli-Q water, dried and ground to a powder. The powdered samples were dried overnight in an oven at $38^{\circ} \mathrm{C}$. All spectra were recorded at $4 \mathrm{~cm}^{-1}$ resolution with 64 scans using a strong Norton-Beer apodization on a Perkin Elmer model 1600 Fourier Transform Infrared Spectrometer (FTIR) from 4000 to $450 \mathrm{~cm}^{-1}$. The spectrometer was equipped with a Diffuse Reflectance accessory that permits DRIFT measurements with high sensitivity on powders. All spectra were corrected using the Kubelka-Munk function.

\section{Observations}

Concholepas has a thick, round and white-brown to purplegrey shell. The outer surface of the shell shows strong lamellose ribs (Fig. 1a). The inner surface of the modern shell is smooth and glossy, and yellowish white in colour. The inner surface of the AJL Holocene shells is yellow-grey in colour and lacks lustre. The older FM Pleistocene fossils are similar, but the two layers of the shells are easily separated from each other. The inner aragonite layer of the older (Pleistocene) shells is commonly white and chalky, especially if weathered.

\subsection{Micro- and nanostructures}

The shell of modern Concholepas is composed of an outer calcite layer and an inner aragonite layer (Fig. 1b-d). The thickness of the outer layer increases from the apex toward the pallial margin (Dauphin et al., 2003; Guzmán, 2004).
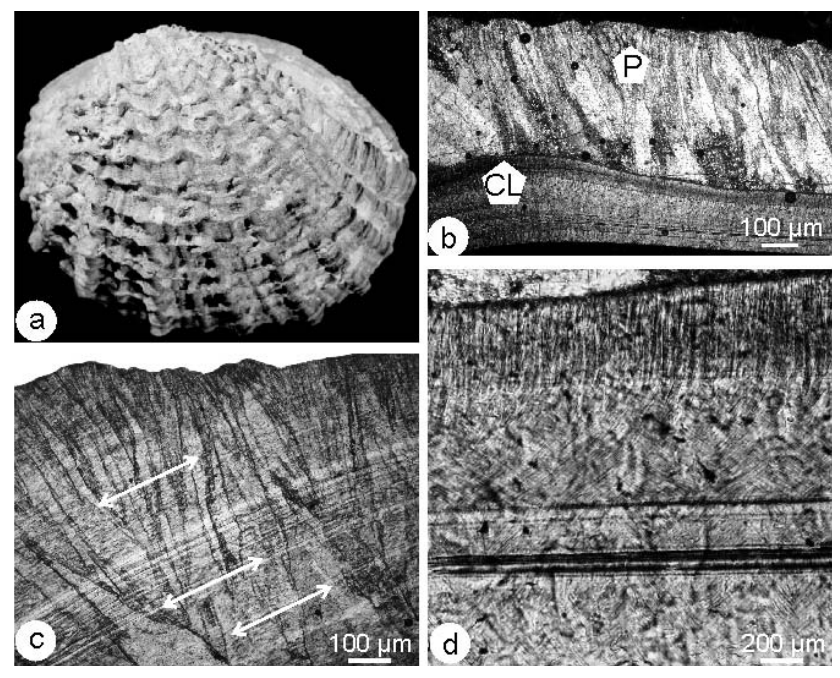

Fig. 1. (a): external view of Concholepas concholepas. (b-d): thin sections in modern shells. (b): outer prismatic layer (P), aragonitic crossed lamellar layer (CL); crossed nichols. (c): outer prismatic layer showing numerous growth lines (arrows). (d): sublayers in the aragonitic inner crossed lamellar layers.

\subsubsection{Calcitic layers}

Modern shells. - Thin sections of the outer prismatic layer have numerous growth lines (Fig. 1c). Each prism is composed of small acicular crystallites (about $2 \mu \mathrm{m}$ long) broadly perpendicular to the growth lines (Fig. 2a, b). Fixed and etched polished surfaces show the presence of an organic matrix (Fig. 2c). AFM images also show the large prismatic units (Fig. 2d), and their subunits (Fig. 2e-i). The acicular crystallites are composed of smaller subrectangular units, aligned in small rows (Fig. 2e, f). Each sub-rectangular unit is approximately $700 \mathrm{~nm}$ long and $180 \mathrm{~nm}$ wide. The subrectangular units are composite structures (Fig. 2f, g). Phase images reveal that each granule is surrounded by a thin dark layer (Fig. 2h, i). The thin layer is probably composed of an organic matrix. The size of the granular units varies from 15 to $200 \mathrm{~nm}$ (Fig. 2i), but the largest ones appear as composite structures.

AJL (Holocene) shell. - The largest growth lines are preserved (Fig. 3a). These growth layers are composed of perpendicular small crystallites enclosed in organic material (Fig. 3b). Different sections display the boundaries between large prisms and transverse sections of acicular crystallites (Fig. 3c). The inner structure of the large crystallites is not as sharply defined as that of modern shells. The regular shape of the acicular crystallites and their arrangement in rows is not preserved, as shown by height and phase AFM images (Fig. 3d-i). Moreover, elongated zones of smooth material, not seen in modern shells, are conspicuous in phase images (Fig. 3f). In the AJL samples, the regular granules described in the modern shells are not preserved (Fig. 3h, i). 

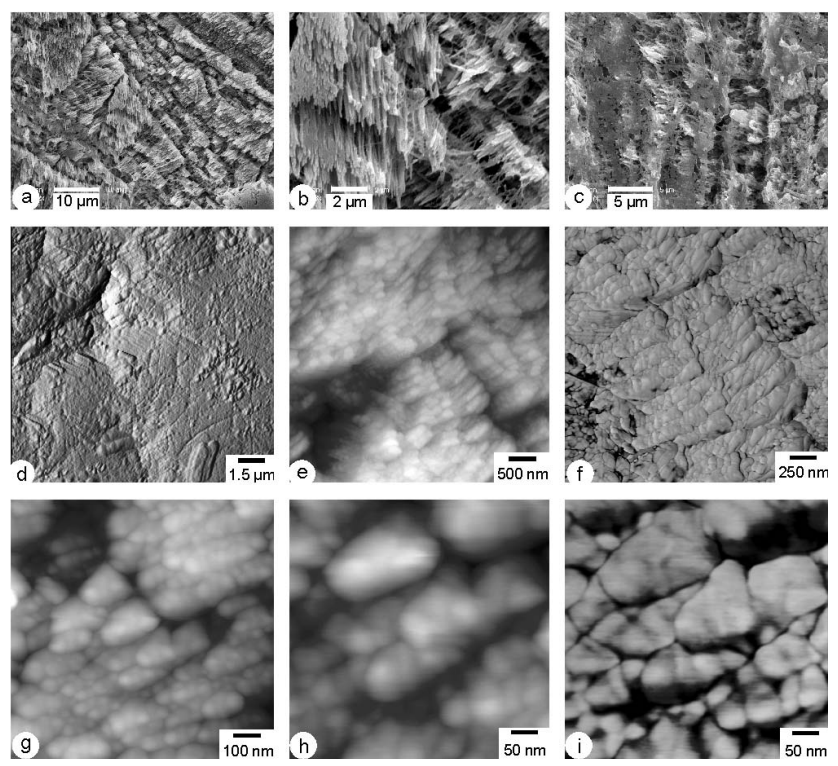

Fig. 2. Polished sections of the outer prismatic layer of modern shells. (a): irregular arrangement of the acicular crystallites in the large prisms, acetic acid 1\% + glutaraldehyde 12\%, $12 \mathrm{~min}$. (b): detail of the same. (c): section showing the organic matrix, acetic acid $1 \%+$ glutaraldehyde $12 \%, 14 \mathrm{~min}$. (d): AFM phase image of the large prismatic units. (e): detail of the same sample, showing the small aligned elongated crystals composing the acicular units seen in (c), AFM height image. (f): detail of (e), phase image. (g): another aspect of the elongated crystals same sample, height image. (h): detail of (g), height image. (i): in the phase image of the same units, the granules seem to be surrounded by a small layer probably of organic composition. (d-i): sections etched with Milli-Q water $\left(16 \mathrm{~h}, 20^{\circ} \mathrm{C}\right)$.

FM (Pleistocene) shell. - Large crystals are preserved, but the growth lines are not as numerous as in the modern shells, and acicular crystallites are not clearly visible (Fig. 4a, c). As in the AJL shell, organic material is present around the crystallites (Fig. 4c). The nanostructure of the large crystals shows small aligned crystals (Fig. 4d-f), but their size and shape differ from those of the modern shells. The size of the small round units is $30-50 \mathrm{~nm}$ (Fig. 4f). In other sections, these small crystals are not visible (Fig. $4 \mathrm{~g}$, h) but smooth zones occur (Fig. 4h, i). A comparison of height and phase images shows that these smooth zones in phase image do not correspond to flat zones in the height image. Thus, it can be inferred that the composition of these zones is most probably organic.

\subsubsection{Aragonitic layers}

Modern shells. - The aragonite inner layer is composed of crossed lamellar sublayers (Fig. 1b-d). The basic structures of each sublayer are similar, and only the orientation of the unit changes, a common feature of the crossed lamellar structure (Fig. 5a, c). The width of the first order lamellae is
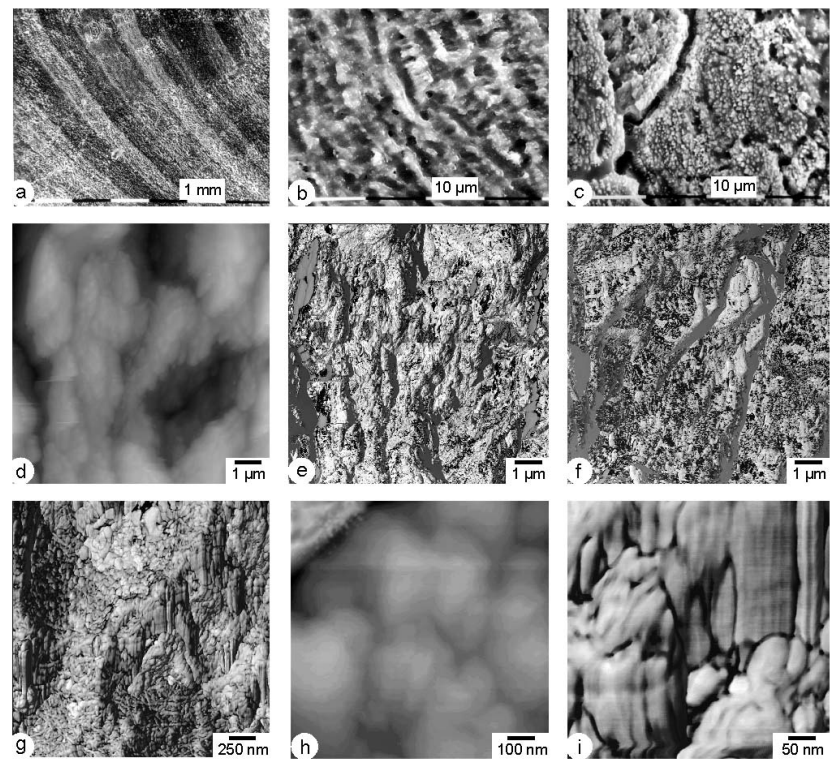

Fig. 3. Polished sections of the outer prismatic layer of AJL shells. (a): section showing the growth pattern, formic acid 5\% $10 \mathrm{~s}$. (b): detail of the acicular crystallites perpendicular to the growth lines, and "embedded" in an organic layer due to the etching. (c): same shells showing another pattern in large prisms cut perpendicularly to the acicular crystallites. (d): irregular pattern of the inner structure of the prisms, AFM height image, $\mathrm{HCl} 5 \%, 5 \mathrm{~s}$. (e): phase image of the same zone. (f): some thin bands of a very smooth material are present, phase image, etched fracture, $\mathrm{HCl} 5 \%, 5 \mathrm{~s}$. (g): detail of (e) showing the irregular nanostructure of the prism, phase image. (h): detail of (f), showing the irregular shape and size of the basic units. (i): detail of $(\mathrm{g})$, phase image.

$10 \mu \mathrm{m}$ or more (Fig. 1b, d, 5b). Each lamella is composed of smaller second order lamellae. The third order lamellae are also complex. Fourth order lamellae are also characterized by a composite structure (Fig. 5d, f). The dark coating surrounding each unit may be indicative of an organic component. The width of each granule is approximately $45 \mathrm{~nm}$.

AJL (Holocene) shell. - First and third order lamellae are well preserved (Fig. 5g-i), but the second order lamellae are indistinct. Some sections show the inner structure of the third order lamellae and their successive subdivision (Fig. 5j-1) according to the same perpendicular scheme. The height image shows the 3-D structure of the lamellae (Fig. 5j): in the foreground, transverse division in sub-rectangular units perpendicular to the length of the lamellae are apparent, whereas in the background and oblique levels, longitudinal subdivisions are seen. The length of a sub-rectangular unit is $210-280 \mathrm{~nm}$. The thickness of the small lamellae is $40-50 \mathrm{~nm}$ (Fig. 51).

FM (Pleistocene) shell. - SEM images of shell sections of similar orientations show variations in preservation (Fig. 6a, b). In some parts of the layer, first order lamellae are separated by thin lacunae (Fig. 6a), while in other parts, some protuberant thickenings between two lamellae are observed 

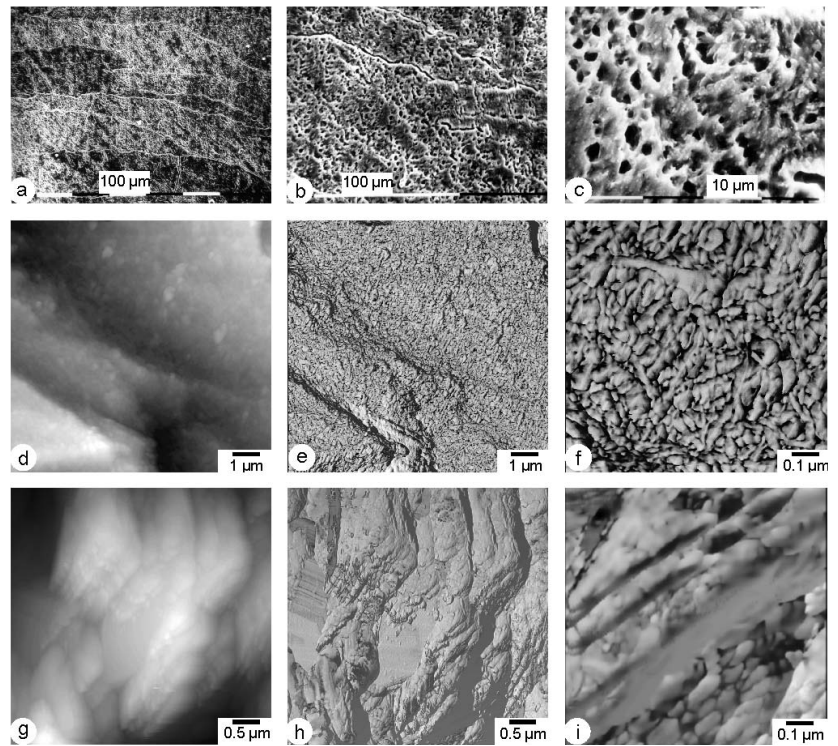

Fig. 4. Polished sections of the outer prismatic layer of FM shells. (a): section showing the large prisms but no growth lines, formic acid 5\% $10 \mathrm{~s}$. (b): detail of Fig. $4 \mathrm{a}$. (c): the growth lines are not well preserved (compare with Fig. 5c), but a "layer" of organic matrix is visible due to the acidic etching. (d): poor preservation of the inner

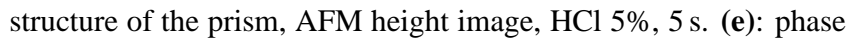
image of the same zone. (f): detail of (d), phase image. (g): height image of the internal surface does not show the inner structure of the prism, $\mathrm{HCl} 5 \%, 5 \mathrm{~s}$. (h): phase image of the same part shows a heterogeneous structure, with very smooth material. (i) detail of (h), showing the soft material and the granules of the prisms, phase image.

Table 1. Tentative assignment of the main amide bands in FTIR spectra.

\begin{tabular}{lccccc}
\hline calicte & recent & AJL & FM & structure & aminoacid \\
\hline amide I & 1685 & 1686 & 1686 & $\beta$ sheets or turns & \\
& 1653 & 1654 & 1654 & a helix & \\
& & & 1648 & random colis & Asn \\
& & & 1637 & $\beta$ sheets & Gln \\
\multirow{2}{*}{ amide II } & & & 1618 & $\beta$ sheets & Gln \\
& & \multirow{2}{*}{1560} & 1578 & & Asp \\
COOH & & & 1718 & & Glu \\
\hline
\end{tabular}

(Fig. 6b). Alterations of the microstructures also appear inside the first order lamellae (Fig. 6c). The third order lamellae are preserved (Fig. 6d-g), but their inner structure is altered: AFM phase images show that these lamellae are heterogeneous, but the regular arrangement seen in modern shells is lost (Fig. 6h, i). The size of the granules is 35$40 \mathrm{~nm}$.
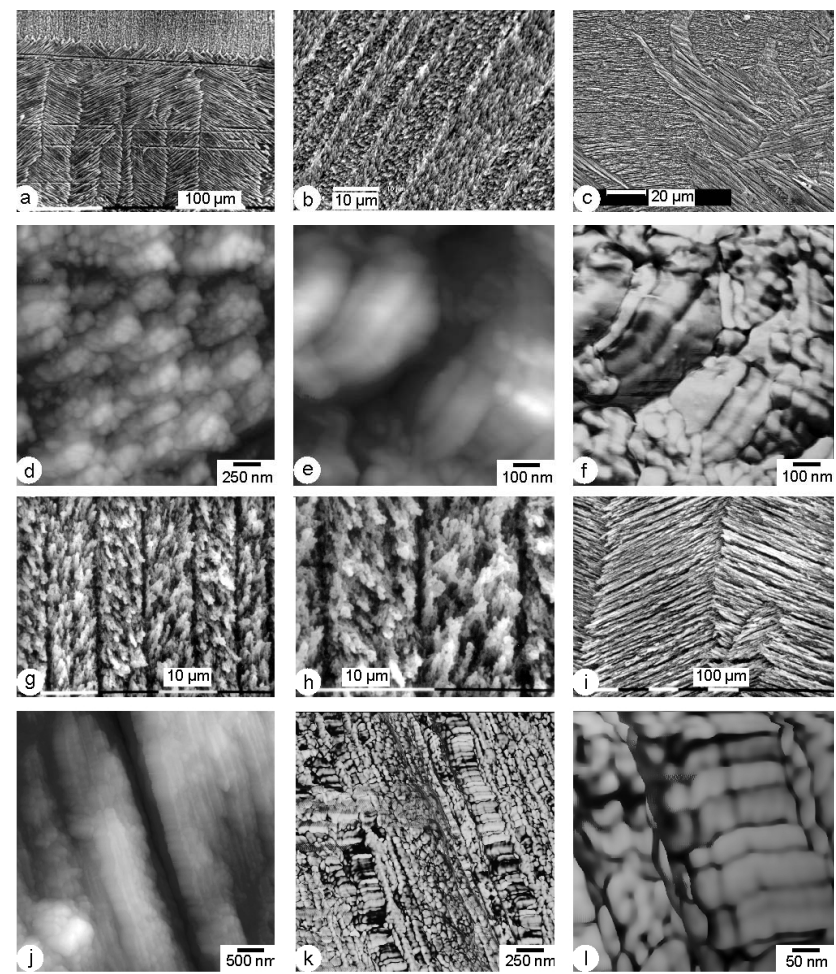

Fig. 5. Polished sections of the inner crossed lamellar layer of modern shells. (a): section showing two sublayers, formic acid $5 \%, 10 \mathrm{~s}$ (b): first and second order elements, acetic acid 1\%+glutaraldehyde $12 \%, 14 \mathrm{~min}$. (c): etched - fixed section: formic acid $0.1 \%+$ glutaraldehyde $2 \%, 2$ min. (d): third and fourth order lamellae, Milli$\mathrm{Q}$ water $16 \mathrm{~h}$. (e) same sample, showing a more detailed view of the third and fourth order lamellae. (f): phase image of the same zone. (g-l): Polished sections of the inner crossed lamellar layer of AJL shells. (g): first and second order elements, formic acid 5\%, $10 \mathrm{~s}$. (h): detail of the same. (i): detail of the second and third order units, formic acid 5\%,10 s. (j): third order lamellae, AFM height image, $\mathrm{HCl} 5 \%, 5 \mathrm{~s}$. (k): detail of (j), showing the inner structure of the lamellae, phase image. (1): detail of (k), phase image.

Table 2. Organic/mineral ratios in the layers, calculated from FTIR data.

\begin{tabular}{lcccc}
\hline & & recent & AJL & FM \\
\hline CALCITE & amide A/878 & 0.07 & 0.019 & 0.04 \\
& amide I/878 & 0.23 & 0.077 & 0.14 \\
ARAGONITE & amide A/860 & 0.08 & 0.099 & 0.08 \\
& amideI/860 & 0.14 & 0.21 & 0.17 \\
\hline
\end{tabular}

\subsection{Bulk composition}

The infrared spectra of the aragonite and calcite groups are characterized by three major bands attributed to $\mathrm{CO}_{3}^{2-}: v 3$ at $1471 \mathrm{~cm}^{-1}$ and two doublets: $v 2$ at $877-848 \mathrm{~cm}^{-1}$ and $v 4$ at 


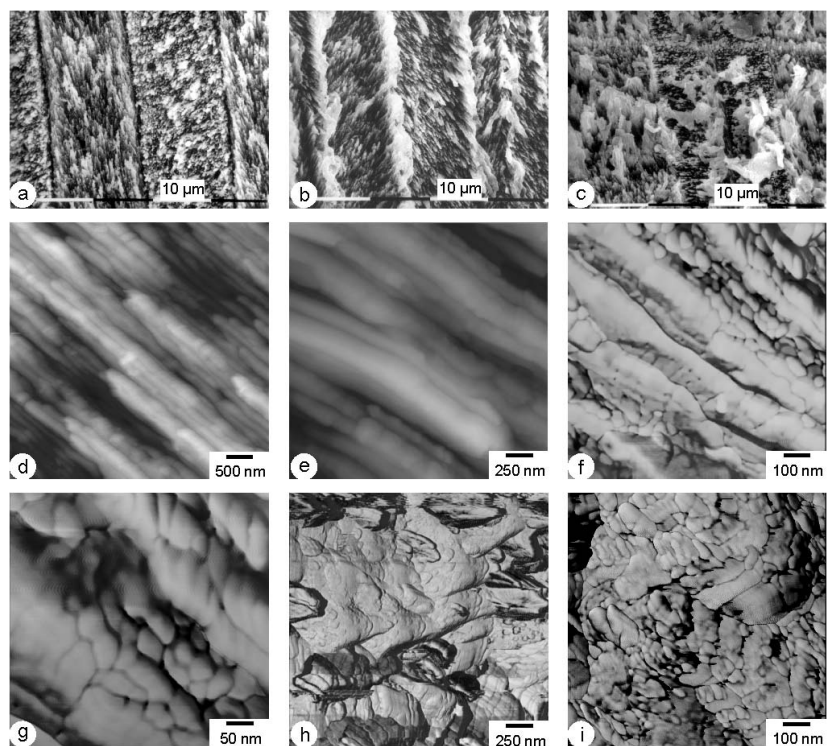

Fig. 6. Polished sections of the inner crossed lamellar layer of FM shells. (a): the first and second order elements, formic acid 5\%, $10 \mathrm{~s}$. (b): first and second order elements: the boundaries between the first order units seem composed of secondary crystals, formic acid 5\%,10 s. (c): diagenetic alteration, formic acid 5\%, $10 \mathrm{~s}$. (d):

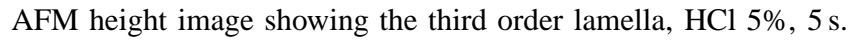
(e): other third order lamella in the same shell. (f): detail of (e) showing the heterogeneous structure of the lamellae, phase image. (g): detail of the basic granules. (h): poor preservation of the third order lamellae, phase image. (i): fracture showing some preserved third order units, phase image, $\mathrm{HCl} 5 \%, 1 \mathrm{~s}$.

$713-700 \mathrm{~cm}^{-1}$ for the aragonite group; and $\nu 3$ at $1429 \mathrm{~cm}^{-1}$, the $v 2$ doublet $877-848 \mathrm{~cm}^{-1}$, and $v 4$ at $713 \mathrm{~cm}^{-1}$, for the calcite group (Adler and Kerr, 1962; Farmer, 1974; Jones and Jackson, 1993). A comparison of the chemical compositions and FTIR data shows a linear correlation between $\mathrm{Mg}$ and $\mathrm{Sr}$ concentrations and some FTIR bands (Dauphin, 1997, 1999; Böttcher et al., 1997). FTIR spectroscopy can also be used to study secondary structure of proteins in a non-crystalline state: the amide I and amide II bands are two major regions of the protein infrared spectrum. Structural information is evaluated mainly from the $1600-1700 \mathrm{~cm}^{-1}$ region (amide I) (Venyaminov and Kalnin, 1990; Barth, 2000). This band is sensitive to changes involving the secondary structure of proteins, of which $\alpha$-helix and $\beta$-sheet are the two most common. In the $\alpha$-helix structure, hydrogen bonds are in a single polypeptide chain while in $\beta$ sheets structure, they are between adjacent chains. However, because of the overlapping of some amide and some $\mathrm{CO}_{3}$ bands in non-decalcified samples, not all of the organic bands are visible in the spectra.

\subsubsection{Modern shells}

The infrared spectra of the outer layer confirm the calcitic mineralogy (Fig. 7a). The $\nu 3$ band, however, is subdivided
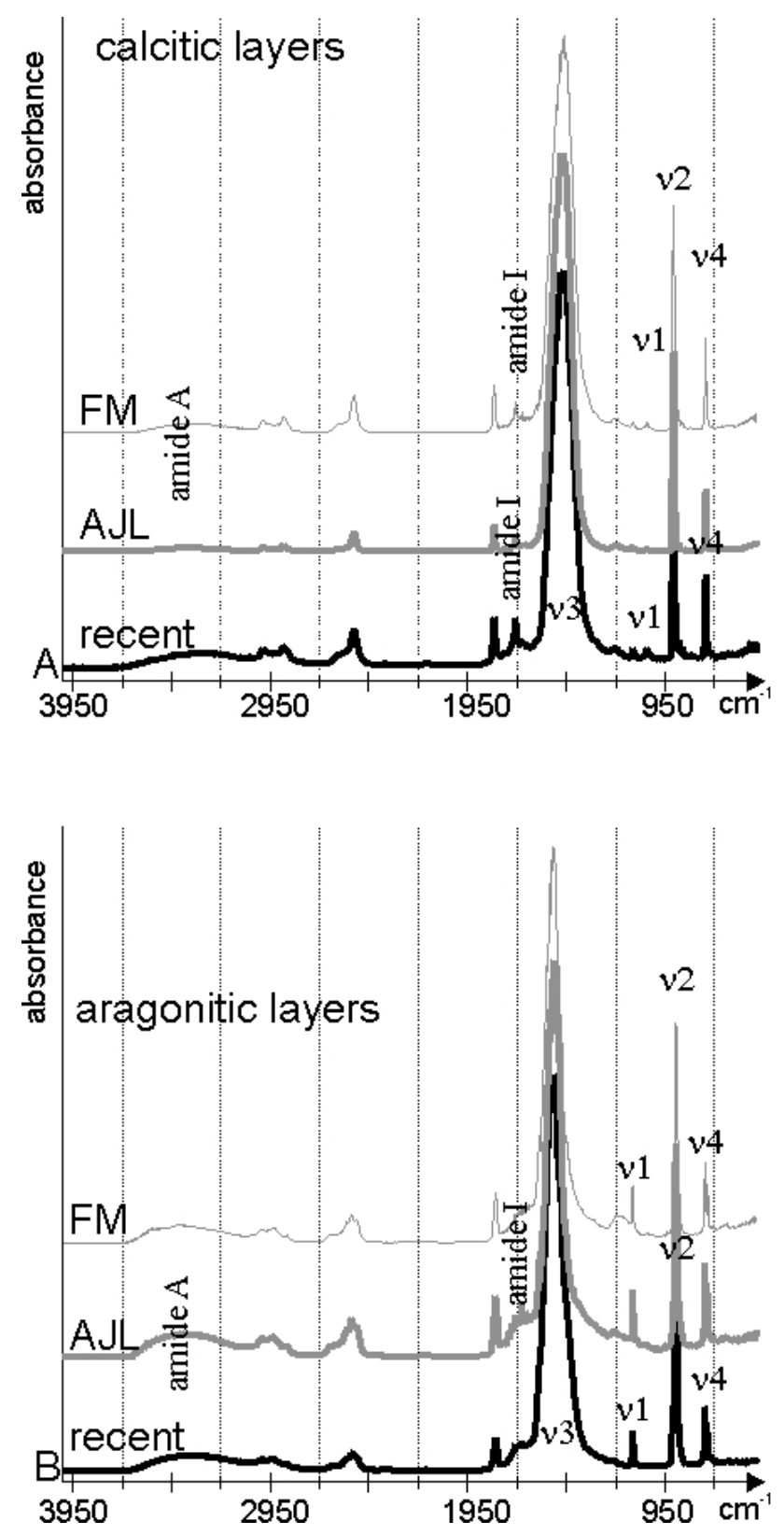

Fig. 7. Infrared spectrometry. (A): outer prismatic layers of modern and fossil shells, showing their calcitic composition and the presence of organic matrix. (B): inner crossed lamellar layers of modern and fossil shells, showing their aragonitic composition and the presence of organic matrix.

into $1457 \mathrm{~cm}^{-1}, 1445 \mathrm{~cm}^{-1}$ and $1436 \mathrm{~cm}^{1}$. Other bands usually present in calcite are also visible: $1176 \mathrm{~cm}^{-1}$ and $1084 \mathrm{~cm}^{1}$. The $v 4$ wavelength indicates low $\mathrm{Mg}$ and $\mathrm{Sr}$ concentrations $(<1000 \mathrm{ppm})$ of the layer. Several bands may be attributed to the organic matrix namely: amide A $\left(3274 \mathrm{~cm}^{1}\right)$ and amide I (Table 1). The main band at $1685 \mathrm{~cm}^{1}$ may be assigned to a turn or a $\beta$-sheet structure. To estimate the organic/mineral ratio in the calcitic layers from FTIR spectra, 
two ratios were used (Dauphin et al., 2003). In modern samples, the ratios have values of 0.23 and 0.07 , for AmideI/878 and AmideA/878, respectively (Table 2). In the inner aragonitic layer of the shell, the $\nu 3$ band is subdivided $\left(1492 \mathrm{~cm}^{-1}\right.$ and $1458 \mathrm{~cm}^{-1}$ ) and only one band of the $v 2$ doublet is present at $863 \mathrm{~cm}^{-1}$ (Fig. 7b). This wavelength indicates low $\mathrm{Sr}(<2500 \mathrm{ppm})$ and $\mathrm{Mg}(<800 \mathrm{ppm})$ concentrations. The amide $\mathrm{A}$ band is at $3310 \mathrm{~cm}^{1}$ and the amide I region may be assigned to $\alpha$-helix structure (Fig. 7b). The amide A/860 ratio is equal to 0.08 , the amide $\mathrm{I} / 860$ ratio is equal to 0.14 (Table 2).

\subsubsection{AJL shell (Holocene)}

The calcitic mineralogy of the prismatic layer is preserved, with low $\mathrm{Mg}$ and $\mathrm{Sr}$ concentrations as indicated by the $\nu 4$ band at $712.5 \mathrm{~cm}^{-1}$ (Fig. 7a). The main $\mathrm{CO}_{3}^{2-}$ band, $v 3$, is subdivided into 4 bands $\left(1458.1 \mathrm{~cm}^{-1}, 1448.5 \mathrm{~cm}^{-1}\right.$, $1441.9 \mathrm{~cm}^{-1}$ and $1430.7 \mathrm{~cm}^{-1}$ ), the most intense being at $1448.5 \mathrm{~cm}^{-1}$. The $1084 \mathrm{~cm}^{-1}$ band is absent. Few organic matrix bands are visible; the amide $A$ band is at $3368.3 \mathrm{~cm}^{-1}$, the main amide $\mathrm{I}$ band is at $1686 \mathrm{~cm}^{-1}(\beta$-sheet structure : Table 1). A band at $1560 \mathrm{~cm}^{-1}$ may be assigned to amide II. The amide $\mathrm{I} / 878$ ratio is equal to 0.08 , and the amide $\mathrm{A} / 878$ is equal to 0.02 (Table 2). The crossed lamellar layer is aragonitic, with numerous bands in the $\nu 3$ regions ( 6 bands from 1498 to $1458.7 \mathrm{~cm}^{-1}$ ) but the main band at $1490.6 \mathrm{~cm}^{-1}$ is characteristic of the aragonitic mineralogy (Fig. 7b). The $863.4 \mathrm{~cm}^{-1}$ part of the $v 4$ doublet shows that the $\mathrm{Mg}$ and Sr concentrations are low (<2000 ppm Sr, $<1000$ ppm Mg). Amide A band is high $\left(3394 \mathrm{~cm}^{-1}\right)$, and amide I region shows numerous bands, the main one being at $1654 \mathrm{~cm}^{-1}$. The amide II band is unique at $1560 \mathrm{~cm}^{-1}$ (Fig. 7a). The amide $\mathrm{I} / 860$ ratio is equal to 0.21 and the amide $\mathrm{A} / 860$ ratio to 0.10 (Table 2).

\subsubsection{FM shell (Pleistocene)}

The calcitic mineralogy of the outer layer is preserved, as shown by the main bands (Fig. 7a). The v3 band is subdivided into $1488 \mathrm{~cm}^{-1}, 1474.4 \mathrm{~cm}^{-1}, 1458.1 \mathrm{~cm}^{-1}$, $1448.2 \mathrm{~cm}^{-1}, 1438 \mathrm{~cm}^{-1}, 1431 \mathrm{~cm}^{-1}$ and $1425.7 \mathrm{~cm}^{-1}$. The highest bands $\left(1488 \mathrm{~cm}^{-1}\right.$ and $\left.1474.4 \mathrm{~cm}^{-1}\right)$ may be due to small relicts of the inner aragonitic layer. Bands at $1176 \mathrm{~cm}^{-1}$ and $1084 \mathrm{~cm}^{-1}$ are also present. The $\nu 2$ band is indicative of low $\mathrm{Mg}$ and $\mathrm{Sr}$ concentrations, whereas the doublet $876-848 \mathrm{~cm}^{-1}$ is well developed. Several groups of bands may be assigned to organic matrices (Table 1). The main amide $\mathrm{I}$ band is at $1685 \mathrm{~cm}^{-1}$ ( $\beta$-sheets). Amide I/876 ratio is equal to 0.14 , and amide $\mathrm{A} / 878$ ratio is 0.04 (Table 2). The $v 3$ band of the aragonitic inner layer has the same range as that of the modern shells $\left(1497 \mathrm{~cm}^{-1}-1458 \mathrm{~cm}^{-1}\right)$ (Fig. 7b). The two bands of the $v 2$ doublet are at $862.3 \mathrm{~cm}^{-1}$ and $844.2 \mathrm{~cm}^{-1}$, and indicative of low $\mathrm{Mg}$ and $\mathrm{Sr}$ concentrations. The amide I region is subdivided, the main band being
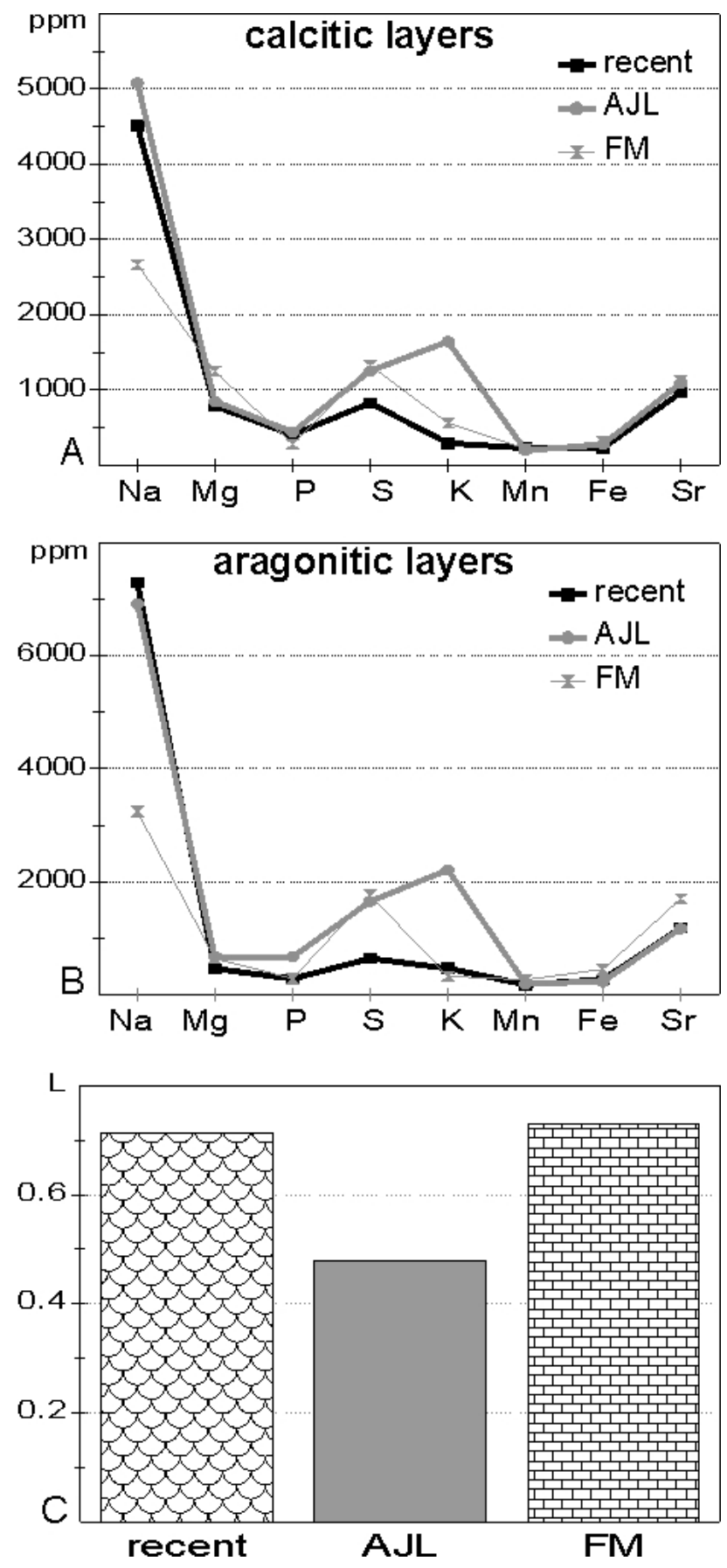

Fig. 8. Elemental composition of the outer prismatic layers (A) and of the inner crossed lamellar layers (B) of the modern and fossil shells. Substitution or L ratios of the aragonitic layers of the modern and fossil shells (C). 

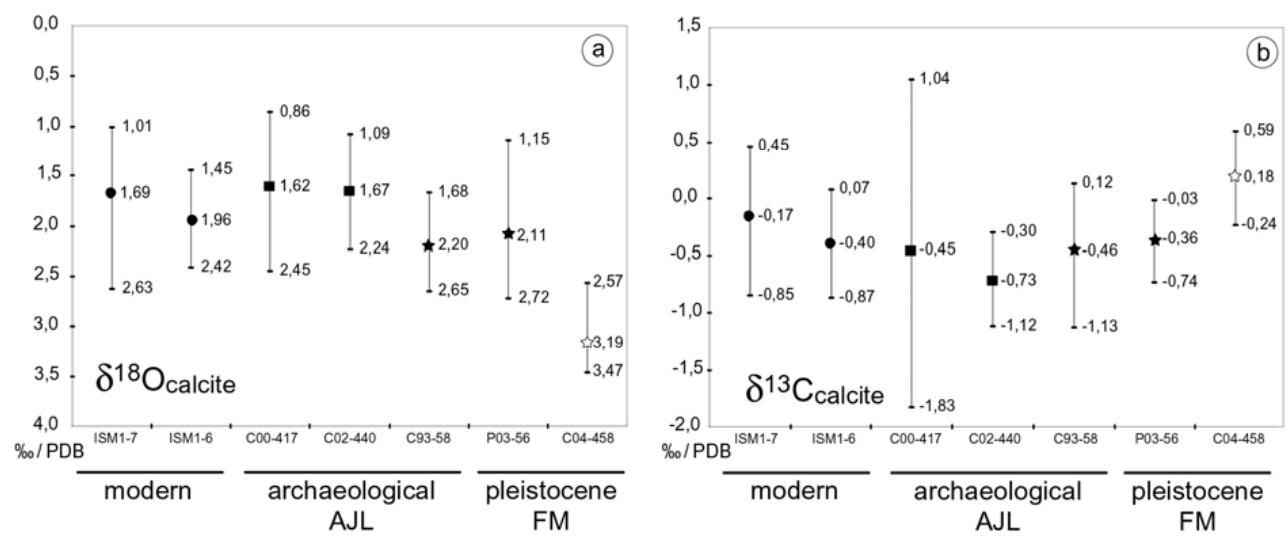

Fig. 9. Range of variation and mean values of $\delta^{18} 0$ and $\delta^{13} \mathrm{C}$ measured in the calcitic layer of modern and fossil shells.

indicative of $\beta$-sheet structures (Table 1). The amide $\mathrm{I} / 860$ ratio is 0.17 and the amide $\mathrm{A} / 860$ ratio is 0.08 (Table 2).

\subsection{Chemical composition (EDS data)}

\subsubsection{Modern shells}

Mollusc shells typically have low contents of minor elements (Turekian and Armstrong, 1960; Harriss, 1965; Masuda and Hirano, 1980). The outer prismatic calcite layer of $C$. concholepas has a low Mg concentration (Fig. 8a), which is even lower than the $\mathrm{Sr}$ concentration. The aragonitic crossed lamellar layer also has low minor element abundance (Fig. 8b). The Loreau ratio is in the lower part of the aragonitic range: $\mathrm{L}=0.71$ (Fig. 8c) (Loreau, 1982).

\subsubsection{AJL shells (Holocene)}

Both calcite and aragonite layers of AJL shells are enriched in $\mathrm{S}$ and $\mathrm{K}$ compared to modern shells (Fig. 8a, b). The calcitic layer is enriched in $\mathrm{Na}$, whereas the aragonitic layer is enriched in P. Because of a small increase in $\mathrm{Mg}$ concentration, the $\mathrm{L}$ ratio is low (Fig. 8c).

\subsubsection{FM shells (Pleistocene)}

These shells are also modified in both layers. The Na concentration is lower than that of the modern shell, but the $\mathrm{Mg}$, $\mathrm{S}$ and $\mathrm{K}$ concentrations are higher (Fig. 8a, b). The aragonite layer is also enriched in Sr. Because the increase in Sr is higher than the increase in $\mathrm{Mg}$, the $\mathrm{L}$ ratio is higher than that of the modern aragonite layer (Fig. 8c).

\section{Discussion and conclusions}

\subsection{Modern and fossil Concholepas}

Macroscopic examination of the fossil shells does not show strong modifications of the external ornamentation. Only the lustre and colour of the inner layer are slightly modified. SEM and AFM observations show that the structures of each layer of both the modern and fossil shells are generally well preserved. However, in the microstructure of the fossil layers there is clear evidence of alteration. Modifications in the structures of the prismatic layers as well as changes in the aragonite layers are different in two fossil sites. FTIR analyses confirmed the preservation of the mineralogy of the fossil sample; however, EDS measurements indicate small changes in $\mathrm{Sr}$ and $\mathrm{Mg}$ concentrations. Additionally, examination of the organic bands confirms that slight alterations occurred in fossil shells.

According to the wave numbers of the amide I bands, the main structure of the proteins of the calcitic layer is $\beta$ sheet. The same structure is also dominant in the fossil samples. The main structure of the organic matrix in the modern aragonite layer ( $\alpha$-helix) is different from that of the calcitic layer. The same main structure is present in AJL shell, but the dominant band in FM shell is $\beta$-sheet structure (Table 1). Tentative assignment of the amide I and amide II bands shows high concentration of acidic amino acids (aspartic acid and glutamic acid), a common feature in mollusc shells. Aspartate and glutamate forms also occur (Table 1). Thus, the organic matrix in the modern calcitic and aragonitic layers is different, and the diagenetic changes in the two layers are dissimilar. Moreover, changes in samples from the two fossil sites are different, the aragonitic layer of the older shells being more altered. These qualitative modifications of the organic matrix are associated with the quantitative changes. The calcitic layers of AJL and FM shells are depleted in the organic matrix, while the changes in the aragonitc layers are more complex (see Table 2).

The small diagenetic changes in $\mathrm{Sr}$ and $\mathrm{Mg}$ inferred from FTIR data are confirmed by microprobe analyses. All the fossil samples are enriched in S and K, but at different levels. The major variation in the content of some elements observed in the archaeological (AJL) shell, with respect to the Pleistocene (FM) shells, may reflect differences in the original 
composition of the biogenic carbonates, or differences in the fossilization processes (organic matter is much more abundant in the archaeological deposit).

\subsection{Comparison with oxygen and carbon stable isotope composition}

Previous analyses of stable isotopic composition of oxygen and carbon of the calcitic layer are available from earlier studies (Falabella et al., 1991; Ortlieb et al., 1997; Labonne and Hillaire-Marcel, 2000), but they had not been submitted to detailed assessment for diagenetic alteration. Here we shall re-examine some of our unpublished results. The variations in the geochemical composition of modern and fossil shells were measured using classical mass spectrometry (carbon and oxygen isotopes). Measurements were conducted on a small segment of the youngest part of the shells, covering a period of growth of a few months to about a year. The results are shown in Fig. 9. The ranges of variation of the $\delta^{18} \mathrm{O}$ and $\delta^{13} \mathrm{C}$ values in each shell correspond to a few tens of measurements.

The oxygen composition shows some variation (means between +2.20 and +1.62 , without considering the FM sample (C04-458) that may have developed under different environmental conditions (water temperature and/or stable isotope composition of the coastal water). The $\delta^{18} \mathrm{O}$ range observed in the modern individual shells is compatible with the temperatures observed annually in this area $\left(13^{\circ}-22^{\circ} \mathrm{C}\right)$. The small variations observed in archaeological and fossil shells (AJL and FM) living during Marine Isotopic Stages 1, 5 and 9 can be attributed to environmental factors and/or diagenetic changes. Nevertheless, these $\delta^{18} \mathrm{O}$ variations are compatible with local environmental changes. The more positive $\delta^{18} \mathrm{O}$ values measured in the oldest fossil shell (FM: C04-458), which was a small beach-worn fragment, may actually correspond to colder water during the Pleistocene. However, microstructural and compositional data show "strong" diagenetic alterations (AJL shell), and it cannot be ruled out that this sample registered some alteration of the original isotopic signal.

A relative homogeneity is observed for the mean values of $\delta^{13} \mathrm{C}(-0.73$ to -0.17$)$, except for the oldest sample (C04458) which has higher values (mean $=+0.18$ ). Both the $\delta^{18} \mathrm{O}$ and $\delta^{13} \mathrm{C}$ values may be interpreted as a manifestation of diagenetic transformations.

In the series of samples utilized in this work we observe that microstructural, nanostructural, and geochemical data are in good agreement. Moreover, they show that there is no direct relation between the state of preservation and the age of the samples.
4.3 Broader implications for paleoenvironmental reconstructions

This study shows that limited diagenetic alteration occurs in fossil shells of the gastropod Concholepas collected along the arid coast of southern Peru and Northern Chile. The aragonitic layer is more affected by diagenesis than the calcite layer. Although these results are consistent with current views, diagenetic processes are still not predictable. Within a single layer of a fossil mollusc shell, microstructure, mineralogy and chemical contents are variable (Barskov et al., 1997; Dauphin, 1988; Dauphin and Denis, 1990, 1999). Diagenetic alteration of the inner aragonitic layer is often observed in middle and late Pleistocene fossils. The thicker, outer layer of calcite is seemingly much more resistant to diagenetic alteration. Isotopic analyses of calcitic shell fragments as old as $\sim 330 \mathrm{ka}$ (isotopic stage 9) present values similar to those measured on more recent (Pleistocene or Holocene) shells (Fig. 9).

In a previous study on diagenetic alteration of Concholepas related to the use of U-series method for dating Pleistocene shells, Labonne and Hillaire-Marcel (2000) also noted that the aragonite layer was subject to strong alteration. According to FTIR data, the calcitic prismatic layer contains more organic matrix than the aragonitic layer. Thus, the greater sensitivity of the aragonite layer to diagenetic alteration may be due to the quality of the organic matrix or to the mineral component. Labonne and HillaireMarcel (2000) expressed reservations about the potential of geochemical studies in the reconstruction of environmental conditions due to mineralogical diagenetic transformations in their samples. Our study confirms the importance of a control of the microstructure and chemical contents of the shells, and that the single verification of the preservation of the mineralogy is not reliable enough. It is not sufficient to check for the variability of diagenetic changes within a fossil site. It is, in fact, necessary to check for variability within a single shell and even within a single layer of a shell. Such an approach would be more promising for the use of this species for palaeoenvironmental reconstructions based on geochemical analyses of shells.

The calcitic mineralogy of the larger part of the C. concholepas shells as well as their sturdiness and large size seems to constitute favourable conditions for the preservation of original geochemical signals. The exceptional dryness of the Atacama Desert coast, which was pervasive during most of the Quaternary period, also probably played a major role in limiting diagenetic alteration of these shells.

Acknowledgements. The field study and collection of samples were made within a scientific agreement between the Universidad de Antofagasta (Antofagasta, Chile) and IRD, and in the framework of the project "Huentelauquén" supported by FONDECYT (Fondo Nacional de Investigación Científica y Tecnológica) and headed by A. Llagostera (Universidad Católica del Norte, Antofagasta). The authors thank S. Caquineau (US094, IRD Bondy) for helping 
to obtain microprobe analyses on Concholepas. This work was made possible with the financial support of PNEDC program of INSU-CNRS (CONCHAS project). Special mention is made in memory of J. Bertaux (IRD, Bondy) who took an important part in the first stages of this study. The stable isotope analyses were done in the LOCEAN, Universite Paris 6-IRD-CNRS-MNHN, with the appreciated help of J. F. Saliège and M. Mandeng Yogo. Thanks also are due to M. Cusack (Univ. of Glasgow), C. T. Williams (Natural History Museum, London) and T. deVries (Burke Museum of Natural History and Culture, Seattle) for their help in improving the manuscript. This study has been made possible by the scientific support from the European Science Foundation (ESF) under the EUROCORES Programme EuroMinScI (BioCalc project), through contract No. ERAS-CT-2003-980409 of the European Commission, DG Research, FP6 and also EU-project CENSOR (Climate Variability and El Nino Southern Oscillation: Implications for Natural coastal Resources and Management, contract 511071). This is CENSOR publication 0345.

Edited by: J. Bijma

\section{References}

Adler, H. H.and Kerr, P. F.: Infrared study of aragonite and calcite, Am. Miner., 47, 700-717, 1962.

Barskov, I. S., Kiyashko, S. I., Dauphin, Y., and Denis, A.: Microstructures des zones calcitiques et aragonitiques des rostres de Goniocamax (Cephalopoda, Belemnitida) du Turonien de Sibérie du Nord, Geodiversitas, 19, 669-680, 1997.

Barth, A.: The infrared absorption of amino acid side chains, Progr. Biophys. Mol. Biol., 74, 141-173, 2000.

Böttcher, M. E., Gehlken, P. L., and Steele, D. F.: Characterization of inorganic and biogenic magnesian calcites by Fourier Transform infrared spectroscopy, Solid State Ionics, 101/103, 13791385, 1997.

Dauphin, Y.: Diagenèse aragonite-calcite chez les Céphalopodes Coléoides: exemples des rostres d'Aulacoceras (Trias de Turquie) et Belopterina (Eocène de France), Bull. Mus. Natl. Hist. Nat. Paris, 4e sér., 10, sect. C, 2, 107-135, 1988.

Dauphin, Y.: Infrared spectra and elemental composition in recent carbonate skeletons: relationships between the $\nu 2$ band wavelength and $\mathrm{Sr}$ and $\mathrm{Mg}$ concentrations, Appl. Spectr., 51, 141-152, 1997.

Dauphin, Y.: Infrared spectra and elemental composition in recent biogenic calcites: relationships between the $v 4$ band wavelength and Sr and Mg concentrations, Appl. Spectr., 53, 184-190, 1999.

Dauphin, Y. and Denis, A.: Analyse microstructurale des tests de Mollusques du Callovien de Lukow (Pologne) - comparaison de l'état de conservation de quelques types structuraux majeurs, Rev. Paléobiol., 9, 27-36, 1990.

Dauphin, Y. and Denis, A.: Diagenèse comparée des phases minérales et organiques solubles dans les tests aragonitiques de nautiles et d'ammonites, Bull. Soc. géol. Fr., 170, 355-365, 1999.

Dauphin, Y., Guzman, N., Denis, A., Cuif, J. P., and Ortlieb, L.: Microstructure, nanostructure and composition of the shell of Concholepas concholepas (Gastropoda, Muricidae), Aquat. Liv. Res., 16, 95-103, 2003.
DeNiro, M. J. and Weiner, S.: Chemical, enzymatic and spectroscopic characterisation of "collagen" and other organic fractions from prehistoric bones, Geochim. Cosmochim. Acta, 52, 21972206, 1988.

DeVries, T., Ortlieb, L., Diaz, A., Wells, L., and Hillaire-Marcel, C.: Determining the early history of El Niño, Science, 276, 965966, 1997.

DuBois, R., Castilla, J. C., and Cacciolatto, R.: Sublittoral observations of behaviour in the chilean "loco" Concholepas concholepas (Mollusca: Gastropoda: Muricidae), The Veliger, 23, 83-92, 1980.

Falabella, F., Planella, M. T., and Pollastri, A.: Análisis de Oxigeno 18 en material malacológico de Chile Central, XI Congr. Nac. Arqueol. Chilena I, 105-121, 1991.

Farmer, V. C.: The Infrared spectra of minerals, Mineral. Soc. Monogr., 4, London, UK, 427 pp., 1974.

Guzmán, N.: Validation d'une approche scléroclimatologique sur la côte du Chili et du Pérou par l'analyse microstructurale et biogéochimique des coquilles du gastéropode Concholepas concholepas [Bruguière, 1789], PhD dissertation, Université de Paris-Sud, France, 219 pp., 2004.

Harriss, R. C.: Trace element distribution in molluscan skeletal material. I. magnesium, iron, manganese, and strontium, Bull. Mar. Sci., 15, 265-273, 1965.

Jones, G. C. and Jackson, B.: Infrared transmission spectra of carbonate minerals, Chapman and Hall, London, UK, 222 pp., 1993.

Kennett, D. J.: Oxygen and carbon isotopic analyses of Concholepas concholepas shells from K4, a late Archaic period archaeological site on the southern coast of Peru, in: Archaeological investigations of K4, an Archaic period site of the south coast of Peru, edited by: Wise, K., Inst. Archaeol., University of California, LA, USA, 1-22, 2003.

Labonne, M. and Hillaire-Marcel, C.: Geochemical gradients within modern and fossil shells of Concholepas concholepas, from Northern Chile: An insight into U-Th systematics and diagenetic/authigenic isotopic imprints in mollusc shells, Geochim. Cosmochim. Acta, 64, 1523-1534, 2000.

Llagostera, A.: Early occupations and the emergence of fishermen on the Pacific coast of South America, Andean Past, 3, 87-109, 1992.

Loreau, J. P.: Sédiments aragonitiques et leur genèse, Mém. Mus. Natl. Hist. Nat. Paris N. S., sér. C, sci terre, 47, 1-312, 1982.

Masuda, F. and Hirano, M.: Chemical composition of some modern marine pelecypod shells, Sci. rep. Inst. Geosc., Univ. Tsukuba, B, Geol. Sci., 1, 163-177, 1980.

Ortlieb, L., Fuentes, E., Guzman, N., and Llagostera, A.: Paleotemperatura del mar en la Bahia de Antofagasta, durante la transicion Pleistoceno-Holoceno: Resultados preliminares de análisis isotópicos seriados en conchas de Concholepas concholepas, VIII Congr. Geol. Chileno (Antofagasta, 1997), Ext. abstr. vol., 366-370, 1997.

Ortlieb, L., Zazo, C., Goy, J. L., Hillaire-Marcel, C., Ghaleb, B., and Cournoyer, L.: Coastal deformation and sea level changes in Northern Chile subduction area $\left(23^{\circ} \mathrm{S}\right)$ during the last $330 \mathrm{ky}$, Quatern. Sc. Rev., 15, 819-831, 1966.

Perrier, C., Hillaire-Marcel, C. and Ortlieb, L.: Paléogéographie littorale et enregistrement isotopique $\left({ }^{13} \mathrm{C},{ }^{18} \mathrm{O}\right)$ d'événements de type El Niño par les mollusques holocènes et récents du nordouest péruvien, Géogr. Phys. Quat., 48, 23-38, 1994. 
Turekian, K. K. and Armstrong, R. L.: Magnesium, strontium and barium concentrations and calcite-aragonite ratios of some recent molluscan shells, J. Mar. Res., 18, 133-151, 1960.

Urey, H. C., Lowenstam, H. A., Epstein, S., and McKinney, C. R.: Measurement of paleotemperatures and temperatures of the Upper Cretaceous of England, Denmark, and the southeastern United States, Geol. Soc. Am. Bull., 62, 399-416, 1951.
Venyaminov, S. Y. and Kalnin, N. N.: Quantitative IR spectophotometry of peptide compounds in water $\left(\mathrm{H}_{2} \mathrm{O}\right)$ solutions. I. Spectral parameters of amino acid residue absorption bands, Biopolymers, 30, 1243-1257, 1990. 